\title{
Ефективність застосування ізометричних вправ у поєднанні з вправами на петлі Гліссона в лікуванні пацієнтів з остеохондрозом шийного відділу хребта
}

\author{
УДК: 616.833.2+616-036: 615.83
}

\author{
Л. Д. Катюкова ${ }^{1}$, В. В. Зінченко ${ }^{1}$, Л. Д. Кравчук², \\ А. П. Русанов ${ }^{1}$
}

${ }^{1}$ ДУ «інститут травматології та ортопедії НАМН України», Київ, Україна

${ }^{2}$ Національний університет фізичного виховання і спорту України, Київ, Україна

\begin{abstract}
Резюме. Мета. Оцінити вплив застосування методики тракції за допомогою петлі Гліссона та ізометричних вправ у відновленні пацієнтів з проявами цервікалгії на тлі остеохондрозу шийного відділу хребта. Методи. Теоретичний комплексний аналіз науково-методичної літератури та джерел, інструментальні методи досліджень (кількісне та якісне оцінювання больового синдрому за ВАШ та оцінювання ступеня порушення життєдіяльності за анкетуванням Oswestry). Результати. Проаналізовано результати власних досліджень лікування 46 хворих (28 жінок і 18 чоловіків) з клінічними і морфологічними проявами гриж міжхребцевих дисків шийного відділу хребта. На підставі отриманих результатів встановлено, що поєднання методу тракції шийного відділу та ізометричних вправ у порівняльному аспекті дають максимальний клінічний ефект, що виявляється в швидкому усуненні больового синдрому, неврологічних симптомів захворювання, нормалізації обсягу рухів у шийному відділі у пацієнтів з клінічними проявами остеохондрозу шийного відділу хребта. Висновки. Застосування тракції на тлі медикаментозного лікування, кінезитерапії (ізометричних вправ) у пацієнтів із дегенеративними змінами у шийному відділі хребта дозволяє підвищити ефективність лікування, що підтверджується результатами власних досліджень. Означений підхід дозволяє досягти максимального функціонального результату.

Ключові слова: тракційна терапія, ізометричні вправи, шийний остеохондроз, фізична реабілітація.
\end{abstract}

\section{Эффективность применения изометрических упражнений в сочетании с упражнениями на петле Глиссона в лечении пациентов с остеохондрозом шейного отдела позвоночника \\ Л. Д. Катюкова ${ }^{1,}$ В. В. Зинченко, Л. Д. Кравчук², А. П. Русанов ${ }^{1}$ \\ ${ }^{1}$ ГУ «Институт травматологии и ортопедии НАМН Украины», Киев, Украина \\ ${ }^{2}$ Национальный университет физического воспитания и спорта Украины, Киев, Украина}

Резюме. Цель. Оценить влияние применения методики тракции с помощью петли Глиссона и изометрических упражнений в восстановлении пациентов с проявлениями цервикалгии на фоне остеохондроза шейного отдела позвоночника. Методы. Теоретический комплексный анализ научно-методической литературы и источников, инструментальные методы исследований (количественная и качественная оценка болевого синдрома по ВАШ и оценка степени нарушения жизнедеятельности по анкетированию Oswestry). Результаты. Проанализированы результаты собственных исследований лечения 46 больных (28 женщин и 18 мужчин) с клиническими и морфологическими проявлениями грыж межпозвонковых дисков шейного отдела позвоночника. На основании полученных результатов установлено, что сочетание метода тракции шейного отдела и изометрических упражнений в сравнительном аспекте дают максимальный клинический эффект, проявляющийся в быстром купировании болевого синдрома, неврологических симптомов заболевания, нормализации объема движений в шейном отделе у пациентов с клиническими проявлениями остеохондроза шейного отдела позвоночника. Выводы. Применение тракции 
на фоне медикаментозного лечения, кинезитерапии (изометрических упражнений) у пациентов с дегенеративными изменениями в шейном отделе позвоночника позволяет повысить эффективность лечения, что подтверждается результатами собственных исследований. Указанный подход позволяет достичь максимального функционального результата.

Ключевые слова: тракционная терапия, изометрические упражнения, шейный остеохондроз, физическая реабилитация.

\title{
The efficiency of the use of isometric exercises in combination with exercises on "skull traction tongs" in the treatment of patients with osteochondrosis of the cervical spine
}

\section{L.D. Katyukova', V.V. Zinchenko', L.D. Kravchuk', A.P. Rusanov'}

${ }^{1} \mathrm{SI}$ «Institute of Traumatology and Orthopedics of the National Academy of Medical Sciences of Ukraine», Kyiv, Ukraine

${ }^{2}$ National University of Physical Education and Sports of Ukraine, Kyiv, Ukraine

\begin{abstract}
Aim. To assess the impact of the application of the traction technique with the help of the Glisson loop and isometric exercises in restoring patients with manifestations of cervicalgia in the background of osteochondrosis of the cervical spine. Methods. Theoretical complex analysis of scientific and methodological literature and sources, instrumental research methods (quantitative and qualitative assessment of pain syndrome according to the VAS and assessment of the degree of impairment in the Oswestry questionnaire). Results. The results of own studies of treatment of 46 patients - 28 women and 18 men with clinical and morphological manifestations of herniated intervertebral discs of the cervical spine are analyzed. Based on the results obtained, the combination of the method of traction of the cervical and isometric exercises in a comparative aspect gives the maximum clinical effect, manifested in the rapid arrest of pain syndrome, neurological symptoms of the disease, normalization of the volume in the cervical spine in patients with clinical manifestations of osteochondrosis of the cervical spine. Conclusions. The use of traction on the background of drug treatment, kinesotherapy (namely, isometric exercises) in patients with degenerative changes in the cervical spine can increase the effectiveness of treatment, which is confirmed by the results of their own studies. This approach allows us to achieve the maximum functional result.
\end{abstract}

Keywords: traction therapy, isometric exercises, cervical osteochondrosis, physical rehabilitation.

Постановка проблеми. Останніми роками значно збільшилася кількість людей, хворих на остеохондроз. Під цим захворюванням зазвичай розуміють дегенеративно-дистрофічний процес, що вражає хребет. В його основі лежить дегенерація міжхребцевого диска 3 подальшим залученням тіл суміжних хребців, міжхребцевих суглобів і зв'язкового апарату. У кожному відділі хребта остеохондроз має типову локалізацію та особливості [1-3].

Остеохондроз вражає всі відділи хребта, але частіше зустрічається у найбільш рухливих і моторно пов'язаних зонах - шийному та поперековому відділах. За даними А. Denner, остеохондроз локалізується на верхньошийному рівні у $29 \%$ випадків, на нижньошийному і шийногрудному - у $20 \%$, що в сукупності більше, ніж $51 \%$ випадків на рівні поперекового відділу [4].

До 50-60 \% звернень до невролога спричинені дорсалгіями, з яких 16-35,4 \% становлять ураження шийного відділу хребта. Останніми роками намітилася тенденція зростання в структурі дорсалгій шийного відділу, що пов'язано зі зміною характеру трудової діяльності та збільшенням статичних навантажень. Критичним віком амбулаторних звернень для даної патології $\epsilon$ вік 30-39 років, а для госпіталізованих - 4549 років у чоловіків і 50-54 роки у жінок $[2,3,6]$.

Вважається, що до 50-річного віку на вертеброгенну цервікалгію (ВЦ) страждає близько $80 \%$ жінок і $60 \%$ чоловіків. У $70 \%$ пацієнтів епізод вертеброгенної цервікалгії короткочасний і здатний мимовільно минати протягом 60 днів, а у $30 \%$ розвивається рецидивуюча цервікалгія, яка $€$ причиною тривалої непрацездатності, інвалідності серед осіб із захворюваннями опорнорухової системи, посідаючи перше місце (14,1$41,1 \%)$ [1].

Аналіз останніх досліджень і публікацій. Вивчення ефективності великої кількості методів лікування шийного остеохондрозу та безпечності їх поєднань дозволить скласти оптимальні схеми терапії з точки зору їх впливу на результат захворювання і виключити негативні побічні реакції під час застосування, у тому числі на стан мозкового кровотоку [7-9]. 
Якщо враховувати, що остеохондроз - вертеброгенна хвороба, що провокується повсякденним статико-динамічним навантаженням, має мультифракторний характер захворювання і характеризується генетичною схильністю, найважливішим має бути етіологічне лікування, яке базується на певних принципах. На сьогодні це реально лише в плані профрілактики остеохондрозу. Перший принцип полягає в необхідності виключення несприятливих статико-динамічних навантажень на уражений відділ хребта [1].

Взаємопов'язаним із першим $є$ другий принuиn - стимулювання активності м'язів хребта. Така діяльність у підсумку забезпечує захисну фріксацію ураженого хребтового сегмента, тобто впливає на основний чинник захворювання (Aker, 1996) [3].

Третій принцип - індивідуалізація, фразовість і комплексність лікування. Вибір засобів лікування для конкретного хворого має бути індивідуальним. Також важливо, щоб використання засобів реабілітації мало щадний характер. Самі по собі вони не повинні бути більш шкідливими, ніж хвороба. Будучи загальним положенням будь-якого виду терапії, цей принцип $\epsilon$ особливо важливим щодо даної хвороби.

ЧетВертий принцип - необхідність впливу не тільки на ділянку хребта, а й на позахребцеві патологічні вогнища, які визначають клінічну симптоматику. Цей принцип відповідає загальним теоретичним положенням про цілісність організму, грунтується на клінічних та клініко-експериментальних положеннях про роль пропріо- та інтероцептивних імпульсів у розвитку вертеброгенних синдромів. Не потребує доведення і необхідність впливу не тільки на джерела патологічних нервових імпульсів, а й на весь організм в цілому, включаючи ендокринні та інші гуморальні механізми, які беруть участь у патогенезі хвороби та компенсаторних реакціях $[1,6]$.

Важливо домогтися не просто ремісії, а ремісії стійкої, з такою фріксацією і конфігурацією хребта, з таким станом нервових, судинних, м'язових і сполучнотканинних елементів, які б забезпечили профрілактику загострень.

Перспективними, патогенетично обгрунтованими, економічно виправданими методами лікування, що дозволяють досягти оптимального лікувального ефекту, $\epsilon$ тракційна терапія та кінезитерапія за рахунок анталгічного, протинабрякового, біомеханічного і регенераторного механізмів впливу. Саме цим методикам лікування i присвячено наше дослідження.

Мета дослідження - оцінити вплив застосування методики тракції за допомогою петлі Гліссона та ізометричних вправ у відновленні пацієн- тів з проявами цервікалгії та тлі остеохондрозу шийного відділу хребта.

Матеріали та методи дослідження. Роботу виконано на матеріалі ДУ «Інститут травматології та ортопедії НАМН України». Вона включає аналіз обстеження та лікування 46 хворих (28 жінок і 18 чоловіків) з клінічними і морфологічними проявами гриж міжхребцевих дисків шийного відділу хребта. Морфологічні зміни оцінювали за даними КТ та / або МРТ. Середній вік пацієнтів становив $42 \pm 10$ років. Всі пацієнти були клінічно обстежені - здійснено обстеження неврологічного статусу, кількісну та якісну оцінку больового синдрому проведено на підставі ВАШ (візуальної аналогової шкали). Для оцінки ступеня порушення життєдіяльності, обумовленого патологією хребта, використано анкетування за Oswestry.

Пацієнтів було поділено на основну (ОГ) і контрольну (КГ) групи. Пацієнти ОГ у поєднанні з курсом медикаментозного лікування, кінезитерапії проходили курс тракційної терапії на базі відділення реабілітації з подальшими рекомендаціями щодо дотримання рухового режиму на постклінічному етапі; пацієнти КГ проходили тільки курс медикаментозного лікування та кінезитерапії в стаціонарі.

Результати досліджень та їх обговорення. При шийному остеохондрозі виконання фрізичних вправ $€$ одним із важливих методів лікування. Унаслідок виконання комплексу поліпшується кровообіг м'язової тканини, що сприяє кращій трофріці пошкоджених частин. Крім того, збільшується еластичність м'язів, підвищується рухливість хребців. Фізичні вправи слід виконувати тільки на стадії ремісії. Під час загострення навантаження на ділянці шиї протипоказано. Велике значення має якість проведення занять, яка полягає не в інтенсивності, а в правильності виконання вправ. Пацієнт не повинен докладати багато зусиль і займатися в максимальному темпі. Вправи потрібно виконувати плавно, без ривків, інакше з'являється біль. У разі виникнення неприємних відчуттів виконання вправ необхідно відразу припинити.

Приблизний комплекс вправ, що рекомендований пацієнтам ОГ та КГ, наведено нижче.

Використання в реабілітаційній програмі методу тракції дозволяє ефективно і в короткі терміни отримати терапевтичний ефрект у пацієнтів, що страждають від неврологічних проявів остеохондрозу хребта. За механізмом розвитку даного захворювання тракція хребта - найбільш фрізіологічно обґрунтований захід.

Сутність тракції полягає в тому, що за допомогою короткочасної або тривалої тяги долаєть- 


\section{Комплекс ізометричних вправ при шийному остеохондрозі}

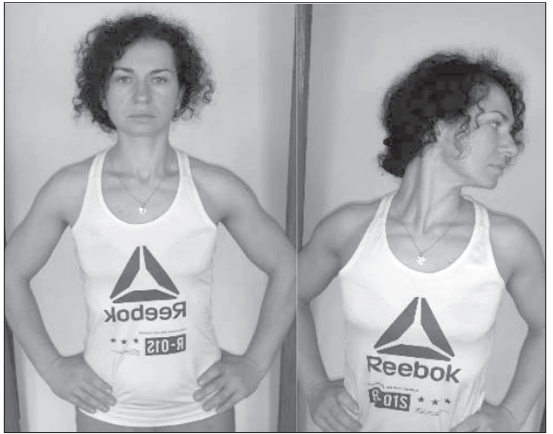

Вправа 1. Вихідне положення - стійка ноги нарізно або сидячи, спина рівно, руки на поясі. Виконання поворотів голови вліво і вправо. Виконувати плавно, підборіддя має розташовуватися над плечем. У разі появи болю знижують амплітуду рухів. Кількість повторень 5-10 разів

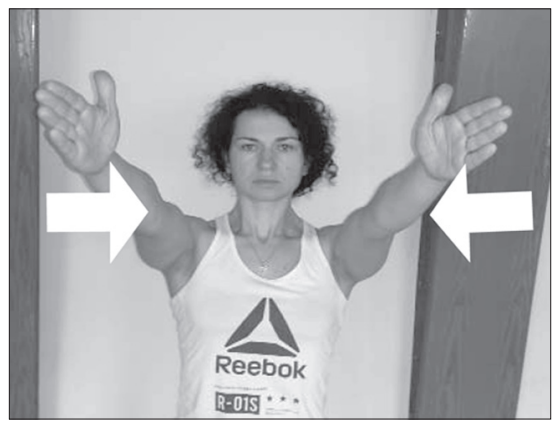

Вправа 2. Вихідне положення - стійка ноги нарізно, руки вперед, долоні всередину. Максимально напружити верхні кінцівки, утримуючи положення, повільно зводити руки, створюючи опір зведенню. Кількість повторень 5-10 разів

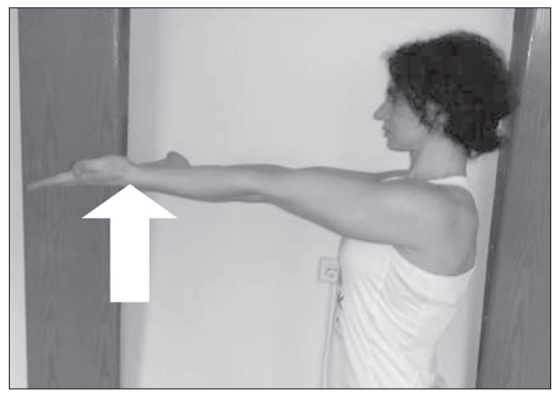

Вправа 3. Вихідне положення - стійка ноги нарізно, руки вздовж тулуба. Максимально напружити верхні кінцівки, повільно підняти руки долонями вгору, створюючи опір підніманню. Кількість повторень 5-10 разів

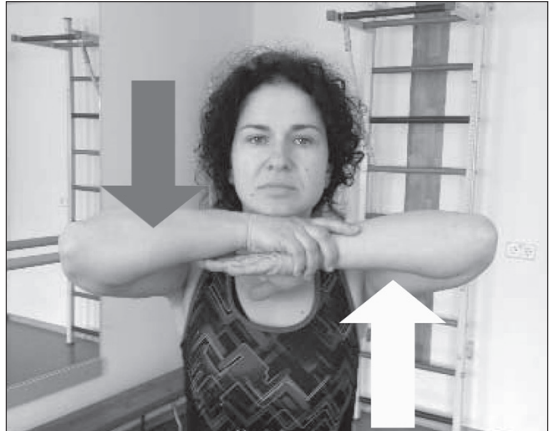

Вправа 4. Вихідне положення - стійка ноги нарізно, руки перед грудьми, права кисть зверху на лівій. Натиснути кистями на підборіддя. Голова утримує положення, створюючи опір підніманню. Кількість повторень 5-10 разів

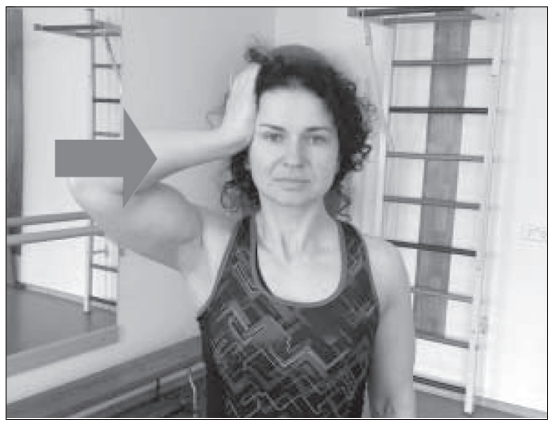

Вправа 5. Вихідне положення - стійка ноги нарізно, права долоня на правій скроні. Натиснути долонею на скроню. Голова утримує положення, створюючи опір нахилу. Кількість повторень 5-10 разів

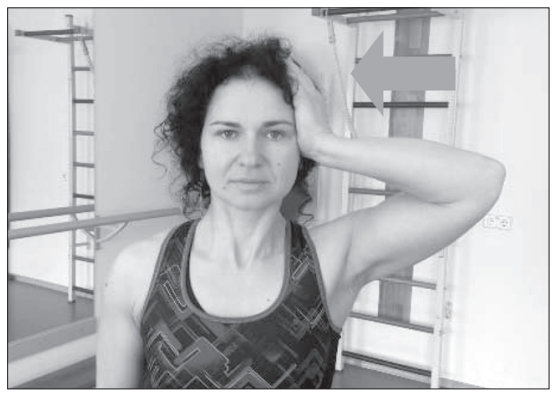

Вправа 6. Вихідне положення - стійка ноги нарізно, ліва долоня на лівій скроні. Натиснути долонею на скроню. Голова утримує положення, створюючи опір нахилу. Кількість повторень 5-10 разів 


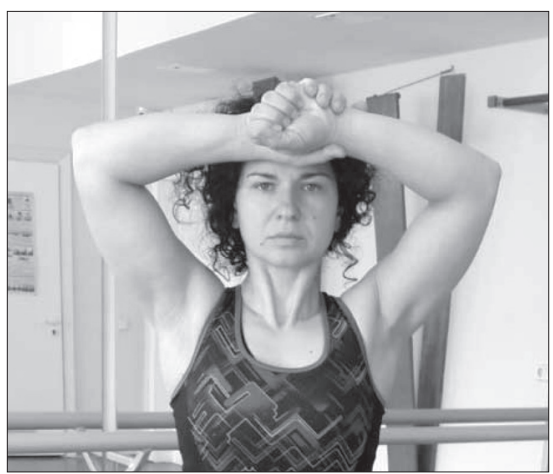

Вправа 7. Вихідне положення - стійка ноги нарізно, руки зігнуті в ліктьових суглобах, права кисть на лівій. Натиснути кистями на лоб. Голова утримує положення, створюючи опір нахилу назад. Кількість повторень 5-10 разів

ся м'язовий спазм, усувається зміщення хребців, деформація вигинів хребта, зміцнюється мускулатура спини в цілому. Розтягнення хребта - це не тільки механічна дія на нього з метою зменшення патологічного впливу грижі диска, а й вплив на рецептори хребтового сегмента, його м'язи і зв'язки.

Майже всі автори, які вивчали ефект тракції, підкреслюють, що зменшуються або зникають поперековий і шийний біль, а потім і сколіоз, фріксовані кіфози, обумовлені контрактурою м'язів хребта [1-5].

У відновленні пацієнтів ОГ ми використовували методику апаратної тракції, що базується на застосуванні інтермітуючого режиму. Під час процедури найбільш оптимальним $\epsilon$ нейтральне положення хворого, при якому виключається натягнення сухожилкового і м'язово-зв'язкового апарату. Інтермітуючий режим здійснювали із зменшенням заданого зусилля на 25-50 \% у кожному циклі, при зміні експозиції (від 30-60 с на максимумі до 1-2 хв на мінімумі). Ступінь витяжіння становила 0,5-1 кг, а тривалість заняття 10-12 хв.

\section{Рекомендовані вправи на петлі Гліссона}

Вправа 1. Максимально нахилити голову вперед, затримати положення протягом 3 с. Повернутися в нейтральне положення. Підняти голову вгору, затримати положення 3 с. Виконати 5 підходів.

Вправа 2. Нахилити голову вправо, затримати положення протягом 3 с. Нахилити голову вліво, затримати положення протягом 3 с. Виконати 5 підходів.

Вправа 3. Розслабити шийний відділ. Малоамплітудні, швидкі рухи «так-так-так». Потім «ні-ніні». По 5 с. Виконати 5 підходів.
Курс тракційного лікування становив 1015 процедур. Курс лікування слід перервати або переглянути схему витяжіння, якщо під час або після процедури значно посилюється біль або з'являються ознаки невропатії. Після тракції використовували фріксацію сегмента 3 допомогою комірця Шанца на 30-60 хв.

Клінічне обстеження продемонструвало, що всі пацієнти скаржилися на безперервний виражений біль у шийному відділі хребта. Середня тривалість захворювання становила $4,1 \pm 0,5$ року, кількість загострень на рік 1,2 \pm 0,3 раза, тривалість останнього загострення 0,8 \pm 0,6 місяця.

В обох групах виявлено позитивну динаміку. Так, під час первинного обстеження пацієнтів за даними ВАШ рівень больового синдрому в середньому дорівнював в ОГ 8,8 $\pm 0,7$ бала, в КГ 8,2 \pm 0,5 бала. Після проведення курсу лікування позитивна динаміка спостерігалася у пацієнтів обох груп (в КГ $-4,6 \pm 0,5$, в ОГ $-2,9 \pm 0,6)(p \leq 0,05)$.

Оцінка результатів лікування з використанням стандартизованого анкетування за Oswestry, що відображає ступінь порушення життєдіяльності у відсотковому співвідношенні, показала, що кращий результат спостерігали у пацієнтів основної групи (рис. 1).

Таким чином, застосування тракції на тлі медикаментозного лікування, кінезитерапії (а саме ізометричних вправ) у пацієнтів з дегенеративними змінами у шийному відділі хребта дозволяє підвищити ефективність лікування, що підтверджується результатами досліджень. Проводити іï вкрай бажано у спеціальних реабілітаційних стаціонарах, де $є$ висококваліфіковані фрахівці, напрацьовані лікувальні методики та відповідні умови проведення лікування. Означений підхід дозволяє досягти максимального фрункціонального результату.

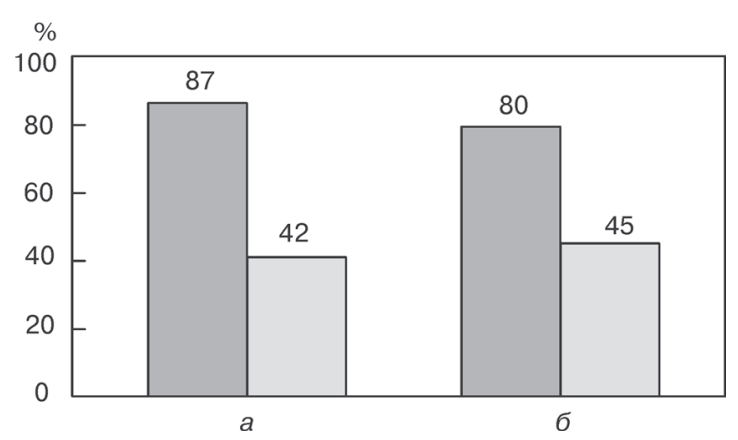

Рисунок 1 - Динаміка лікування за стандартизованим анкетуванням Oswestry у пацієнтів основної (a) та контрольної (б) груп до $(\square)$ та після $(\square)$ лікування $(p \leq 0,05)$ 


\section{Висновки.}

Встановлено, що поєднання методу тракції шийного відділу та ізометричних вправ у порівняльному аспекті дозволяють досягти максимального клінічного ефректу, що виявляється в швидкому усуненні больового синдрому, неврологічних симптомів захворювання, нормаліза-

\section{Література}

1. Егоров Н. А. Оздоровительная физическая культура при остеохондрозе позвоночника у детей и подростков / Н. А. Егоров, С. А. Егорова, Л. В. Белова // Теория и практика физ. культуры. - 2007. - № 6. - С. 23-29.

2. Ситель А. Б. К вопросу об эфффективности различных лечебных техник в мануальной терапии / А. Б. Ситель, В. М. Смирнов, А. Ю. Нефёдов // Мануальная терапия. - 2001 - № 1. - С. 123-133.

3. Aker P. D. Conservative management of mechanical neck pain: systematic overview and meta-analysis / P. D. Aker, A. R. Gross, C. H. Goldsmith, P. Peloso // BMJ. - 1996. - Nov 23, N 313(7068). - P. 1291-1296.

4. Denner A. Muskuläre profile der wirbelsäule. Band 2. Analyse und trainingskonzept. - Cologne, Germany: Sport \& Buch Strauss, 1995. $234 \mathrm{p}$.

5. Ernst E. Manual therapies for pain control: chiropractic and massage / E. Ernst // Clinical J. of Pain. - 2004. - N 20 (1). - P. 8-12.

6. Felson D. T. Osteoartritis: new insight. Part 2: Treatment approach / D. T. Felson // Ann. Intern. Med. - 2000 - N 133. - P. 726-737.

7. Goldie I. Evaluation of the effects of different forms of physiotherapy in cervical pain / I. Goldie, A. Landquist // Scand. J. Rehab. Med. - 2007. N 2-3. - P. 117-121.

8. Green C. A systematic review of craniosacral therapy: biological plausibility, assessment reliability and clinical effectiveness / C. Green, C. W. Martin, K. Bassett, B. A. Kazanjian // Complementary Therapies in Medicine. - 1999. - N 7(4). - P. 201-207.

9. Gross A. R. Patient education for mechanical neck disorders (Cochrane Review) / A. R. Gross, P. D. Aker, C. H. Goldsmith, P. Peloso // Cochrane Library, Issue 3. - Oxford: Update Software, 2003. - P. 66-74. ції обсягу рухів у шийному відділі у пацієнтів 3 клінічними проявами остеохондрозу шийного відділу хребта.

Перспективи подальших досліджень: спостереження й оцінка стану пацієнтів з клінічними проявами остеохондрозу шийного відділу хребта на етапі відновлення через 6 міс. та більше.

\section{References}

1. Egorov, H.A., Egorova, S.A., Belova, L.V. (2007). Ozdorovitelnaya fizicheskaya kultura pri osteohondroze pozvonochnika u detey i podrostkov [Healthy physical culture with spinal osteochondrosis in children and adolescents]. Teoriya i praktika fizicheskoy kultury - Theory and practice of physical culture, 6, 23-29 [in Russian].

2. Sitel, A.B., Smirnov, V.M., Nefyodov, A.Y. (2001). K voprosu ob effektivnosti razlichnyih lechebnyih tehnik $\mathrm{v}$ manualnoy terapii [To the question of the effectiveness of various therapeutic techniques in manual therapy]. Manual'naya terapiya - Manual therapy, 1, 123-133 [in Russian].

3. Aker, P.D., Gross, A.R., Goldsmith, C.H., Peloso, P. (1996). Conservative management of mechanical neck pain: systematic overview and meta-analysis. BMJ, Nov 23, 313(7068), 1291-1296.

4. Denner A. (1995). Muskuläre profile der wirbelsäule. Band 2. Analyse und trainingskonzept. Cologne, Germany: Sport \& Buch Strauss.

5. Ernst, E. (2004). Manual therapies for pain control: chiropractic and massage. Clinical J. of Pain, 20 (1), 8-12.

6. Felson, D.T. (2000). Osteoartritis: new insight. Part 2: Treatment approach. Ann. Intern. Med., 133, 726-737.

7. Goldie, I., Landquist, A. (2007). Evaluation of the effects of different forms of physiotherapy in cervical pain. Scand. J. Rehab. Med., 2-3, 117121.

8. Green, C., Martin, C.W., Bassett, K., Kazanjian, B.A. (1999). A systematic review of craniosacral therapy: biological plausibility, assessment reliability and clinical effectiveness. Complementary Therapies in Medicine, 7(4), 201-207.

9. Gross, A.R., Aker, P.D., Goldsmith, C.H., Peloso, P. (2003). Patient education for mechanical neck disorders (Cochrane Review). Cochrane Library, Iss. 3. Oxford: Update Software. P. 66-74. 